2 Fedotov M. R. Etimologicheski slovär chuvaşskogo iazyka.- Cheboksary, 1996. T. 1-2.

3 Starostin S., Dybo A., Mudrak O. Etymological Dictionary of the Altaic Languages. - Leiden; Boston: Brill, 2003. - Vol. 1. - P. 858. (A-K); Vol. 2. - P. 859-1556. (L-Z); Vol. 3. - P. 1557-2096. (Indices)

4 ÖztopçuKurtuluş. Dictionary of the Turkic languages: English, Azerbaijani, Kazakh, Kyrgyz, Tatar, Turkish, Turkmen, Uighur, Uzbek. - London: Routledge, 1996. - 422 r.

5 Qaidar Ä. Qazaqtaranatıliäleminde.-Almaty: Daik-Pres, 2009. - 780 b.

6 Akademicheski slovär başkirskogo iazyka: v 10 t. / pod red. F.G. Hisamitdinova. - Ufa: Kitap, 2011. T. 1. $-432 \mathrm{c}$.

\title{
МРНТИ 16.21.23
}

\author{
Сейтбатқ̧ал Ә.Б. ${ }^{1}$ Бектемірова С.Б. ${ }^{2}$ \\ 1,2 әл-Фараби атындавы ҚазҰУ, \\ Алматье , Қазақ̆стан
}

\section{ХХІ ҒАСЫРДЫН БАСЫНДАҒЫ ТҮРКІ ТІЛДЕС ХАЛЫҚТАРДЫН ӘЛЕМДІК ТАРАЛЫМЫ}

Мақалада түркі халықтарының әлем өркениетінде

Мақалада түркі халықтарының әлем өркениетінде алатын орны шынайы деректерге сүйене отырып айтылады. Теориялық тұрғыдан қазақ және бауырлас түркі, шетел ғалымдарының зерттеулеріне және түркітану ғылымының қайнар көзі саналатын еңбектерге шолу жасалады. Түркі тілдес халықтардың орналасуы мен әлемдік таралымы тарихи дәуірлермен сабақтаса сипатталады. Бір тектен шыққан түркі тілдерінің ақпарат қорын түзу, оны жүйелеп ұсыну басшылыққа алынды. Мәліметтер қоры келесі бағыттарды қамтуды жоспарлауда: қазіргі дүние жүзіне таралған түркі тілінде сөйлеушілердің санын анықтау,түркі тілдерінің таралымын WebGIS жүйесінде көрсету,түркі тілдерінің жіктелуі туралы мәліметтерді саралау, қазіргі түркі тілдерінің мәртебесін көрсету, жойылу қаупі төнген түркі тілдерін жандандыруға нақты бағдарлама негізіндеұсыныс жасау.Қазақ түркітану ғылымына жаңа серпін әкелетін ғылыми жұмыс - Түрік Одағының дамуынаөзіндік үлесін қосады.

Түйін сөздер: алтайтану, түркітану, ареалды лингвистика, лингвожағрапия, түркі халықтары, түркі тілдері

\author{
Seytbatkal A., ${ }^{1}$ Bektemirova $S .{ }^{2}$ \\ ${ }^{1,2}$ Al-Farabi Kazakh National University, \\ Almaty, Kazakhstan
}

\section{WORLD SPACE OF TURKIC-SPEAKING PEOPLES AT THE BEGINNING OF THE XXI CENTURY}

Abstract
The article reveals the role of Turkic peoples in world civilization. Theoretically, a review of the research of Kazakh and Turkic, as well as the works of foreign scientists which are the source of Turkic science is conducted. Localization and world distribution of Turkic-speaking peoples is characterized by a combination of historical epochs. It is necessary to form and systematize the database of Turkic languages of the same origin. The database includes the following directions: to determine the number of speakers of Turkic languages in the modern world, to show the distribution of Turkic languages in the WebGIS system, to analyze data on the classification of Turkic languages, to demonstratethe status of modern Turkic languages. It is planned to make proposals on the activation of Turkic languages under threat of extinction on the basis of the specific program. The scientific work, which brings a new impetus to the Kazakh Turkology, contributes to the development of the Turkic Union.

Keywords: altaistics, Turkology, areal linguistics, linguogeography, Turkic peoples, Turkic languages 


\author{
Сейтбаткал А.Б., ${ }^{1}$ Бектемирова С.Б. ${ }^{2}$ \\ ${ }^{1,2}$ КазНУ им. аль-Фараби, \\ 2. Алматы, Казахстан
}

\title{
МИРОВОЕ ПРОСТРАНСТВО ТЮРКОЯЗЫЧНЫХ НАРОДОВ В НАЧАЛЕ ХХІ ВЕКА
}

Аннотация
В статье раскрывается роль тюркских народов в мировой цивилизации. Теоретически проводится обзор исследований казахских и тюркских, а такжетрудовзарубежных ученых, являющихся источником тюркологической науки. Локализация и мировое распространение тюркоязычных народов характеризуется сочетанием исторических эпох. Следует формировать и систематизировать базу информации тюркских языков одного происхождения. База данных включает следующие направления: определить числа носителей тюркских языковв современном мире,показать распространение тюркских языков в системе WebGIS,анализировать данныео классификации тюркских языков, показать статус современных тюркских языков. Планируется внести предложения по активизации тюркских языков, находящихся под угрозой исчезновения, на основе конкретной программы. Научная работа, которая приносит новый импульс в казахскую тюркологию, вносит свой вклад в развитие Тюркского Союза.

Ключевые слова:алтаистика, тюркология, ареальная лингвистика, лингвогеография, тюркские народы, тюркские языки

Кіріспе.Мың жарым (1500) жыл уақыт бұрын Еуразия даласында Ұлы Түрік қағанаты дүниеге келді. Ол сақ, ғұн мемлекеттерінің заңды жалғасы әрі мұрагері болды. Түрік қағанаты корей түбегінен Қара теңізгедейінгі кең байтақ өлкеге иелік етті .

Б.з.б. 1 мыңжылдықта Еуразия далаларында мекен еткен сақ, үйсін, қаңлы, ғұн, сарматтардың көне түрік тілінде сөйлеген халықтар екені баршаға мәлім. Олардың төл жазуы болған және қалалар салып өз мемлекеттігін қалыптастырған. Темір дәуірінде өмір сүрген түркі тектес халықтардың адамзат өркенитіне берген дүниесі айдай анық. Түркілердің арғы тегі саналатын Ботайлықтардың жылқыны алғаш қолға үйретіп, тұрмысында пайдалануы олардың жаратылыс жайлы терең білімін дәлелдесе, «Аң стилі» өнері мензергерлік бұйымдардыңкөркемдігі сана-сезімінің биіктігін көрсетеді.

Ерте орта ғасырда түрік тілі өркендеп, түрік жазуы халық арасында қанат жайды. Түрік жазба әдебиетінің негізін салған Йоллығ тегін сияқты ғұламалар тасқа қашалып жазылған мәңгі мұраларынаманат етіп қалдырды.Түрік қағанаты тұсында сақ, ғұн дәуірінен де көп бұрын пайда болған жазу әдеби норма дәрежесіне көтерілді.Көне түрік әдеби тілінде ежелгі түріктер Талас, Шу, Орхон, Енесайбітіктастарын дүниеге әкелді. Түркітану, түркі филологиясын зерттеудеосы ескерткіштердің және орта ғасырда жазылған М. Қашқаридың «Түрік сөздігінің» орны ерекше.

Бұл сөздік түркі әлемін тілдік тұрғыдан зерттеуге негіз болатын еңбек. Сонымен қатар әлемдік ғылым кеңістігінде салыстырмалы-тарихи тіл білімінің алғашқы үлгісін көрсеткен ғылыми еңбек саналады. Мұнда бай тілдік деректермен қатар түркі халықтарының сол кездегі қоныстанған аймақтары мен этнографиясынан да құнды деректер бар (1-сурет).

1-сурет. XI ғасырдағы түркі халықтарының қонысы 


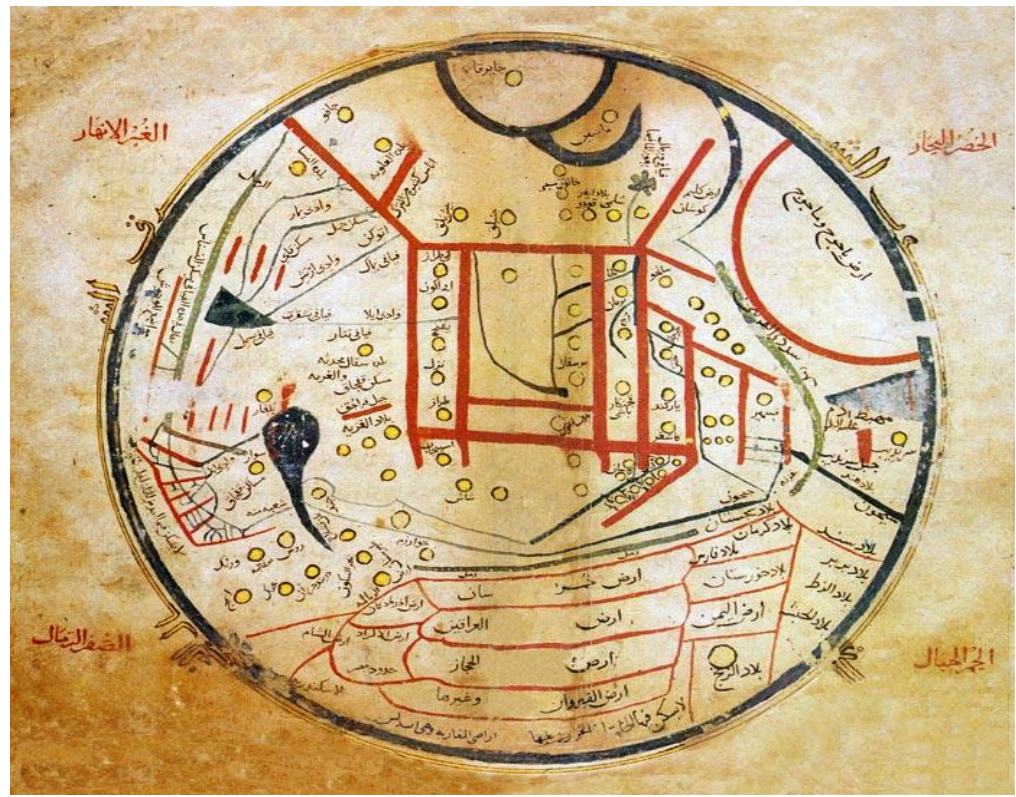

Әдістеме.Түркітану қазіргі кезде түркі тілдерін зерттейтін ғылымның атауы ретінде де қолданылып жүр. Түркітану - түркі тілдерін тұтастай алып зерттейтін жалпы тіл білімі іспеттес. ТүркітануXX ғасырда жалпыдан жалқыға өтіп, жеке түркі тілдері негізгі зерттеу нысанынаайналды. Осы кезеңде ұлттық тілтанушы ғұлама ғалымдар келіп, тіл білімінің берік іргетасын қалап, кейінгіге мол мұра қалдырды. А.Байтұрсынұлы, Қ.Қ.Жұбанов, Ә.Т.Қайдар, Р.С.Сыздық,Ғ.Айдаров, Т.Жанұзақ т.б. ғалымдар қазақ тіл біліміне көп еңбек сіңірді.

Қырғыз тіл білімінде Б.М. Юнусалиев, Б. Орузбаева, Т.Ахматов, Т.К. Сартбаев, татар тіл білімінде М.З.Закиев, Д.Г.Саттаров, башқұрт тіл білімінде Ж.Кигенбаев, А.А.Юлдашев, Н. Ишбулатов, 3. Ураксин, С.Миржанова, А. Харисов, қарақалпақ тіл білімінде Д.Насыров, Е.Бердімұратов, О. Доспанов, өзбек тіл білімінде С. Ибрагимов, Ф. Абдуллаев, А.И. Гулямов, Ш. Шабдурахманов, Ғ. Абдурахманов, А. Шерматов, С. Муталлибов, Ш. Рахматуллаев, әзірбайжан тіл білімінде М. Ширалиев, А. Демиарчи-заде, А.А. Ахундов, Ф. Зейналов, А.А. Абдуллаев, түрікмен тіл білімінде А. Азимов, Б. Чарыяров, М. Хыдыров, Т. Таджмұратов, З. Мұхаммедова, қарайым тіл білімінде С.М. Шапшал, К.М. Мұсаев; құмық тіл білімінде Ю.Д. Джанмаев, А.Т. Базиев, қарашайбалқар тіл білімінде А.М. Аппаев, У.Б. \Алиев, М.А. Хабичев, М. Ахматов, ұйғыр тіл білімінде Э.Р. Тенишев, Ә.Т. Қайдар, Г. Садвакасов, Т. Талипов, А. Шамиева, Р.А Авакова, тува тіл білімінде А.А. Пальмбах, Д.А. Монгуш, З.Б. Арагачи, алтай тіл білімінде Т.М. Тощакова, А.Т. Тыбыкова, хакас тіл білімінде М.И. Боргояков, Д. Патачакова, О. Субракова, шор түркітану ғылымы: Ш.С. Сат,М.Д. Бичеоол, саха тіл білімінде Л.И. Харитонов, Н.К. Антонов, Е.И. Коркина, В.В. Наделяев, Н.Д. Дъячковский, чуваш тіл білімінде В.Г. Егоров, И.П. Павлов, И.А. Андреев, Л.П. Сергеев қажырлы еңбек етті. Аталған ғалымдардың еңбегінен қазіргі түркі тілдері туралы негізгі мәлімет аламыз. Жекетүркі тілдерінің құрылымы,дыбыстық ерекшеліктері, сөзжасам жүйесі, сөйлем құрылысын XX ғасырдың басында ұлттық тіл ғалымдары зерттеді. Қазақ тіл білімінен мысал келтірсек: “Осы орайда КСРО түркологиясының басшысы академик А.Н. Кононовтың бір сөзі еске түседі. 20-шы жылдардан бастап әр түріктектес республикаға орталықтан мамандарды жолдадық. Басында жергілікті тілді үйреніп, кейіннен Мәскеуден жетекшілік жасап отыру үшін. Әр жерге ғалымдарды жібердік. Тек қана Қазақстанға ешкімді аттандырмадық. Өйткені, ол кезде Ахмет Байтұрсынұлы, Құдайберген Жұбановтар бар еді ғой... Яғни қазақ зиялылары - КСРО түркологиясы мен алтаистикасының іргесін қалаған ғалымдар екені дау туғызбайтын ақиқат. А.Н. Кононов, Н.А. Баскаков сынды ірі түркітанушы ғалымдардың ұстаздары да - сөзсіз, біздің арыстарымыз болған»[1, 296].

Талқылау.Түрік тілдерін дәуірлеу Алтай кезеңінен басталады.Түркі тілдері - алтай әулеті бұтағының бір бөлігі.Алғашқы руникалық жазбалардың сырын ашқан дат ғалымы В.Томсен. Ол 1893 жылы құпия болып келген жазудың сырын тауып, түркі тілдес халықтардың төл жазуы екені дүниежүзі алдында дәлелдеді. XVIII-XIX ғ.ғ.шетел ғалымдары түрік тілдес халықтардың мәдениетін, 
тарихын, тілін зерттеп, ғылым айналымына енгізді. Олардың көрнекті өкілдері В.В. Радлов, М.М. Казем-Бек,П.М. Мелиоранский, А.Н. Самойлович, С.Е. Малов,Э.Н. Наджип,Э.В. Севортян, К.К. Юдахин, Н.А. Баскаков А.М. Щербак, Н.З. Гаджиеват.б. ХХ ғасырда өмір сүрген көрнекті түркітанушыН.А. Баскаковтың топтастыруы әлі күнге дейін өзінің маңызын жоғалтқан жоқ. Ол өзіне дейінгі жасалған бөліністерді қорытындылаған топтастыру болып саналады.Көрнекті түркітанушы Н.А. Баскаков Түркі тілдерінің тарихын төмендегідей кезеңдерге бөледі:

1) алтай дәуірі;

2) ғұн дәуірі;

3) көне түркі дәуірі;

4) орта түркі дәуірі немесе негізгі түркі тайпаларының дамуы мен қалыптасу дәуірі;

5) жаңа түркі дәуірі немесе түркі халықтарының қалыптасуы мен даму дәуірі;

6) ең жаңа дәуір немесе түркі тілдерінің Қазан төңкерісіне дейінгі және одан кейінгі даму дәуірі.

Түркі тілдері дамуының Алтай дәуірі уақытын дәл айту мүмкін емес, белгісіз уақыттан б.з.д. III ғасырға дейінгі кезеңді қамтиды. "Б.з.д. І мыңжылдықта Еуразия даласында Ордостан Донайға дейін антикалық және ежелгі шығыс жазуларында скифтер, сақтар, ғұндар, сарматтар атымен әйгілі болған халықтар қоныстанды”[2, 240].

Ғұн дәуірі б.з.д. III ғасырдан б.з. V ғасырына дейінгі уақытты қамтиды.Б.з.д.V ғасырда Оңтүстік Моңғолия мен Ордоста түркі тілдес ғұндардың мекен еткені жайлы деректер бар. Бұл аймақты ғұндардың атамекені ретінде санасақ болады. Түркі тілдес халықтар б.з.д. 3-2 мыңжылдықтан бастап, қазіргі күнге дейін, Қиыр Шығыстан Қара теңізге дейінгі кең байтақ далада қоныс тепкенін тарихи деректер айғақтайды. Ғұндардың ұлы көші мен батысқа жасаған жорықтары олардың Еуразияның батысына одан да терең енуіне ықпал етті. Еділ патша кезінде ғұн империясы Қара теңіз жағалауынан Днестрге дейінгі аралықты өз иелігіне қосты.

Көне түркі дәуірі Еділдің өлімінен кейін, яғни, V ғасырдың ортасынан басталады. Бұл кезде Еділ құрған патшалықтың орнына батыста Бұлғар мен Хазар мемлекеті пайда болды. Олардың иеліктеріне Еділ, Донөзенінің бойы, кавказ етегі, Қара теңіз бен Қырым даласы кірді. Көне түркі дәуірінде түркі тілдері тармақтана, бөліне түсті. “Батысты V-IX ғасырларда көптеген түркі тайпаларының басын қосқан хазар және бұлғар тілдері өмір сүрді. Түркі тілдерінің орталық аймақтарында қыпшақ, оғыз, қарлұқ одақтарының тілдері бөлініп шықты, ал шығыста көк түрік, ұйғырлар жене қырғыздар одағы құрылды. Көне түркі дәуіріндегі ескерткіштер Орхон-Енисей немесе Көне түркі жазулары деп аталады. Түркі халықтарының тасқа қашалып жазылған алғашқы жазба есктеркіштері осы әліпбимен жазылған.IV ғасырда қазіргі батыс Моңғолиядан Донға, Қара теңіз жағалауына дейін көшіп-қонған түркі тайпасы, Ғұн одағы ыдыраған соң, тарих сахнасына бұлғарлар мен хазарларды, IX ғасырда печенегтер мен оғыздарды алып келеді. Түркі тайпаларының ішіндегі ең күштісі де, ықпалдысы болған қыпшақтар XI ғасырда Балқаш пен Ертістен бастап, Прут өзеніне дейінгі ұлан-байтақ өлкеде көшіп-қонған. Түркі ру-тайпалары туралы алғашқы мәлімет біздің жыл санауымызға дейінгі дәуірде жазылған қытай жылнамаларында берілген. Одан кейінірек көне армян, көне еврей, көне грузин, араб жылнамалары мен тарихи жазбаларында ертедегі түркі тайпалары туралы хабар берілген. Х ғасырдан бастап түркі тайпалары туралы мәлімет орыс жылнамасы мен жазбаларында кездесе бастайды.

Орта түркі дәуірі (IX-XV ғ.) Қарахан және Моңғол кезеңі деп екіге бөлінеді. Бұл кезеңде қазіргі түркі тілдерінің негізі жасалды. Батыста бұлғар мен хазар тілдерінің бірігуінен чуваш тілі пайда болды, қыпшақ-бұлғар тайпасы тілдері, қыпшақ-половец, қыпшақ-ноғай, оғұз-бұлғар, қарлұқ-үйғыр тілінен тува, қарақас, якут тілдері, көне қырғыз тілі калыптасты. Осы кезеңде жазылған жазба ескерткіштер араб графикасында сақталған" [3, 332]. Орта түркі дәуірі ғылым-білімнің дамып, мәдениеттің гүлденген дәуірі болды. Көптеген ғылыми еңбектер, әдеби көркем шығармалар дүниеге келді. Түркі жұртынан шыққан Махмұд Қашғари«Түрік сөздігін», Жүсіп Баласағұн«Құтты білік» дастанын, әлемнің екінші ұстазы әл-Фараби мен ибн-Сина өзінің мол мұрасын, Қожа Ахмет Йассауи«Даналық кітабын», Ахмет Йүгінеки«Ақиқат сыйы» аталатын теңдессіз туындаларын жарыққа шығарды. Осы кезеңде түркі тілдес халықтардың таралу ареалы шығысқа, араб, парсы қалалық аймақтарына бағытталды.

«Жаңа түркі дәуірінде (XV-XIX ғ.) қазіргі түркі тілдерінің диалектілері және кейбірінің әдеби тілдері қалыптасты. Батыста бұлғар диалектісінен - чуваш тілі; қыпшақ-бұлғар тобынан - татар және башқұрт тілдері; қыпшақ-половец тобынан - қарайым, қарашай-балқар, құмық, қырым татары тілдері; қыпшақ-ноғай тобынан - ноғай, қазақ және қарақалпақ тілдері; оғыз-бұлғар тобынан гагауыз тілі, балқан түркілерінің диалектілері; оғыз-селжүк бірлестігінен - түрік, әзірбайжан тілдері; 
оғыз-түрікмен тобынан - түркімен тілі, қарлұқ-хорезм және қарлұқ-ұйғыр тобынан - өзбек, ұйғыр тілдері тарады. Шығыста тува, қарақас, якут, камасин, шор, сағай, белтір, қойбал, качи, телеуіт, төлеңгіт, қызыл, тува, құманды, чалкан, кюэрик, сары ұйғыр, қазіргі қырғыз т.б. тілдер бөлектенеді.

Ең жаңа дәуірде - XX ғасырда бұрынғы Кеңестер Одағындағы көптеген түркі тайпасы, тайпа одақтарының тілдері, диалектілері бірігіп, ұлт тілдері пайда болды. Жазуы жоқ және жазуы кеш дамыған халықтардың әліпбиі жасалды, әдеби тілі өркендеді»[3, 332].

«Соңғы бес ғасырда жер шары халқының саны күрт өсті. Оның бірнеше тұрғыдан әсері бар. Бұл тілдердің барлығы дерлік өз сөйлеушісіне ие болды дегенді білдіреді»[4, 244]. Бес ғасыр бұрын қазіргі түркі халықтары қалыптасып дами бастады. Осы кезеңде халық саны өсіп, ұлттық әдеби тіл бой көрсетті. Тіл болу үшін бірінші алғы шарт тілдің атауы болу керек. Атаусыз тіл де жоқ, өйткені ол туралы ешкім ештеңе айта алмайды. Түркі халықтарында ұлт атауы мен тіл атауы бір. XIV ғасырда түркі халықтары этникалық тұрғыдан бірігіп, ұлт ретінде ұйысты. Ұлт атаулары этникалық мәнге ие болды да, тілге де сол атау берілді. Мысалы, Қазақтар қазақ тілінде, өзбектер өзбек тілінде, ноғайлар ноғай тілінде, қарақалпақтар қарақалпақ тілінде сөйлейді.

Нәтиже.«Түркі тілдері - Қиыр Шығыстан Жерорта теңізі мен Үнді мұхитына дейінгі кең байтақ өлкеде тұрып жатқан 40-қа жуық туыстас халықтардың тілі. Түркі тілдері - алтай семьясы бұтағының бір бөлігі. Қазіргі таңда түркі тілдері 170 млн-ға жуық адамдардың сөйлеу тілі (2008). Олардың басым көпшілігі ТМД елдері мен Түркия, Иран, Әзірбайжан, Өзбекстан мемлекеттерінде тұрақтанған. Ресей, Қытай, Қазақстан секілді іргелі елдердің әрқайсысын 12-15 млн. түркі тілдес халықтар мекендейді. 2008 жылғы мәлімет бойынша түркі тілдес халықтар өкілі Еуропалық одақ - 2 млн (Ұлыбритания, Германия және Францияны қоспағанда), АҚШ - 1 млн., Германия - 5 млн., Франция - 0,4 млн., Ұлыбритания - 0,4 млн., Моңғолия - 80 мың, Жапония - 0,1 млн., Канада - 0,2 млн., Бразилия - 0,1 млн., Аргентина - 0,1 млн., Украина и Белоруссия - 0,3 млн., Латин Америкасы (Бразилия және Аргентинаны қоспағанда) - 0,8 млн., Австралия - 60 мың. Дүниежүзінің қалған аймақтарында - 1,4 млн». [5, 826] (1-кесте).

«Түркі тілдерінде сөйлейтіндердің жалпы саны - 250 миллиондай, тіпті кейбір деректерде 250 миллионнан астам деп көрсетілуде»[6, 456]. Түркі әлемінің мәдени мұрасы қазіргі таңда әлемде ана тілдерінде сөйлетін 300 млнға жуық халықтың ұлттық қазынасы болмақ [7,482].

Қазіргі түркі тілдерінің грамматикасы бір, сөздік қоры ұқсас, тек сөздердің дыбысталуында айырмашылық бар. Түркі тілдерінің өзіндік құрылымы бар. Ол жалғамалы тілдер тобын құрайды. Қыпшақ тобына кіретін қазақ, ноғай тілінде сөйлейтіндер бұлғар тобындағы чуваш тілінде, оғыз тобындағы гагауыз тілінде, сондай-ақ шығыс ғұн бұтағының ұйғыр-оғыз тобына кіретін хақас тіліндегі адамдармен тілдесіп, түсінісу өте қиын. Оның себебінаталған тілдердің тарихынан және жағрапиялық орналасуынаніздеген жөн. Тіл өзгермелі құбылыс және оған сыртқы-ішкі факторлар, атап-айтқанда әлеуметтік-саяси, эконимикалық жағдай ықпал етеді.Бұл тілдер бір-бірінен көне түркі дәуірінде оқшауланып, барыс-келіс азайған және басқа тілдік отбасыға жататын тілдермен араласып өзара ықпалға түскен. “Өткен ғасырдың өзінде атақты түркітанушы В.В. Радлов түркі ұлысы секілді ұлан-байтақ өлкеге, үш алып құрлыққа бірдей тарай қоныстанған халық жоқтың қасы деген еді. Өкінішке орай, таяу тарихи кезеңге дейін бір ғана тілде сөйлеп келген халықтың тілі әр түрлә тарихи, саяси, әлеуметтік себептен жеке говорларға ажырап, уақыт озған сайын бір-бірінен алшақтай түскені белгілі. Соның салдарынан қазіргі таңда 40 шақты жеке дара түркі тілдері қалыптасып отыр. Көп ғасыр бойы байланысы болмай, арақатынасы үзіліп қалғандықтан, бұл тілдердің біразы түсінісуге де ауырлап кеткен»[8, 288]

«Орта Азия және көршілес аймақтардағы этникалық, тарихи мәдени орталықтарды зерттегенде тіл маңызды этникалық белгі болатындықтан, ол әрдайым есте болуға тиіс. Орталық Азияның түркі тілдес халықтары ежелден алтай тілдері дүниесімен ғана емес, үнді-еуропа тілдерімен де қатынасқан.

Тілдердің материалдық және типологиялық, құрылымдық ұқсастығы бір-бірімен тығыз байланысты. Олардың аражігін анықтаудың өзі кейде дүдәмал келтіріп, қиындық туғызады. Алтай, орал тілдерінің ортақ белгілері - үндестік заңы, жыныстық белгінің жоғы, есімдердің тәуелденуі, предлог орнына септеулік шылаулардың қолданылуы, анықтауыштардың анықталатын сөздердің тек алдында тұруы. Сонымен қатар ортақ түбір мен қосымша морфемалардың барлығын кірме элементтер деп түсіндіру де қиын.

Ертедегі түркі тілдерінің үнді-еуропалық тілдермен араласы (қатынасы) грек-түркі, хетт-түркі, тохар-түркі, үндіиран-түркі лексикаларының қатарласуымен дәлелденеді. Мұнымен қатар ертедегі орал-алтай тілдерінің үнді-еуропа тілдерімен де алыс туыстығы бар деген болжам туады» $[9,344]$. 
XXI ғасырда әлем кеңістігіндегі түркі халықтарының таралымы мен орналасуына байланысты ғылыми тұжырымдар мен пікірлер соңғы уақыттарда көптеп қарастырылуда. XXI ғасыр басындағы түркі тілдес халықтардың әлемдік таралымын, қазіргі түркі тілдерінде сөйлейтін этностардың статистикалық көрсеткішін, дүниежүзіндегі түркі халықтарының санын, қазіргі түркі халықтарының генеалогиялық топтастырылуын, қазіргі түркі халықтарының таралу және тіркелу ареалын, қазіргі түркі ұлттық автономияларын нақты көрсететін еңбектер мен электронды ресурстар кеңінен таралуда.

XXI ғасырда әлемдегі түркі халықтарының саны 300 млнға жақындады. Олар әлемнің барлық түкпіріне тараған. Түркі тілдерінде сөйлеушілерінің саны бұл санға сәйкес келмейтіні заңдылық. Өйткені тіл бірлігі мен этникалық бірегейлік әрқашан сәйкес келе бермейді. Дегенмен түркі тілінде сөйлейтін халықтар да алты құрлыққа қоныс аударып, тіршілік етуде.Сондықтан олардың экономикалық, әлеуметтік және мәдени даму көрсеткіші бірдей емес. Бұл олардың тілінде анық байқалады.

1-кесте. Қазіргі түркі тілдері

\begin{tabular}{|c|c|c|c|c|c|}
\hline 1 & алтай & 16 & қырымшақ & 31 & түрік \\
\hline 2 & әзірбайжан & 17 & құман & 3 & түрік-месхетин \\
\hline 3 & балқар & 18 & құмық & 33 & т рікмен \\
\hline 4 & башқұрт & 19 & қырғыз & 34 & туркоман \\
\hline 5 & гагауыз & 20 & нағайбақ & 35 & өзбек \\
\hline 6 & долған & 21 & ноғай & 36 & ұйғыр \\
\hline 7 & сары ұйғыр & 22 & салар & 37 & хакас \\
\hline 8 & қарайым & 23 & сібір татарлары & 38 & халадж \\
\hline 9 & қазақ & 24 & татар & 39 & челкан \\
\hline 10 & қарақалпақ & 25 & телеңгіт & 40 & чуваш \\
\hline 1 & қараманлиды & 26 & телеуіт & 41 & чұлым \\
\hline 12 & қарапапах & 27 & тофа (саха) & 42 & шор \\
\hline 13 & қарашай & 28 & трухмен & 43 & юрюк \\
\hline 14 & қашқай & 29 & туба & 44 & якут \\
\hline 15 & қырым татарлары & 30 & тувин & & \\
\hline
\end{tabular}

Қорытынды.Қазіргі таңда әлемде 6 тәуелсіз (2-сурет), 13 ұлттық автономиялытүркі мемлекеті бар (3-сурет). 6 егемен елдеана тілі мемлекеттік тіл деңгейінде өмірдің барлық саласында қолданылады. Ал қалған 13-інде ұлттық тіл ретінде қызмет атқарады. “Татар, башқұрт, саха сияқты түркі тілдері орыс тілінің ықпалында, екінші мемлекеттік тіл ретінде қолданылып, Ресейдің пошта, қатынас байланыстарында қолданылуы шектеуген тіл санатына жатады. Тіпті тұрмыстық қажетті ғана атқаратын түркі тілдері де бар екені рас» [10, 360].

Түркі тілдерінің орналасқан жері - тіл иелерінің көпшілігі қоныстанған ел немесе мемлекет. Ал түркі тілдерінің таралған аумағы олардың ареалы (лат. area - алаң, кеңістік). «Ареал»тіл таралымында жағрапиялық, демограпиялық, әлеуметтік мәнде қолданылады. Яғни, орналасқан жері атамекені, ал таралуы - осы атажұрттан шығып әлемге жайылуы.

\section{2-сурет.Қазіргі тәуелсіз түркі мемлекеттері}

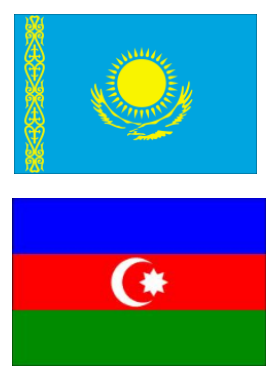

Қазақстан- 73 \% халық (2010)

Әзірбайжан - 90 \% аса халық (1999)

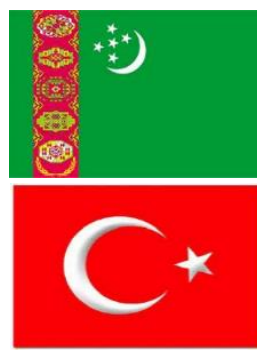

Түрікменстан - 85 \% жуық халық (2003)

Түркия - 70-75\% халық (2008) 


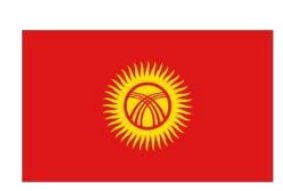

Қырғызстан - $85 \%$ aса

халық (2009)

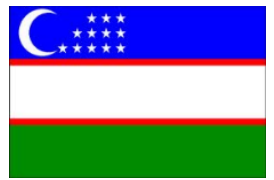

Өзбекстан - 80\% халық

(1996)

3-сурет. Қазіргі түркі ұлттық автономиялары
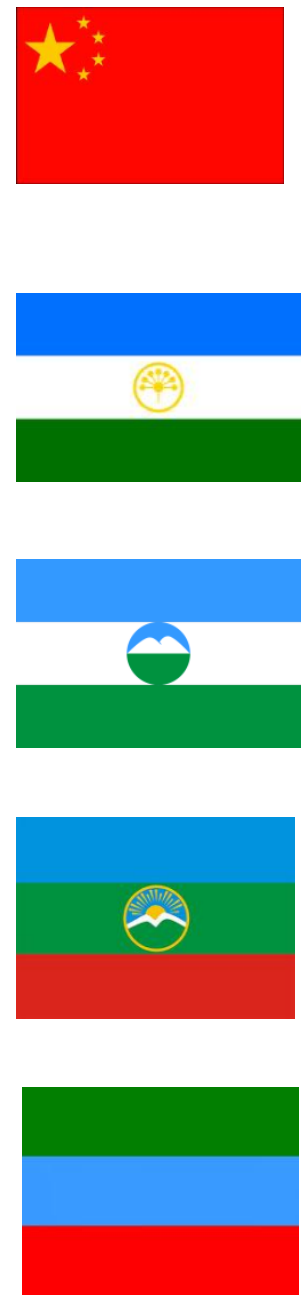

Дағыстан Республикасы 20,50\% (2002) халық (әзірбайжандар, құмықтар, ноғайлар)

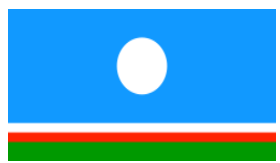

Саха(Якутия)Республикасы $-47 \%$ халық

халық

(башқұрттар,татарлар, чуваштар)

Кабардин-Балқар Республикасы - 14,8 \% (2002) халық(балқарлар,түріктер,татарлар)

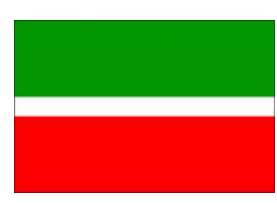

Татарстан Республикасы - $56 \%$ (2002) халық (татарлар,башқұрттар, чуваштар)

Қарашай-Черкес Республикасы - 44,3 \% (2002) халық (қарашайлар, ноғайлар)

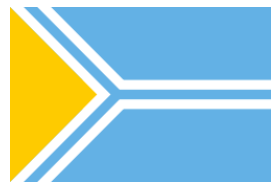

Тува(Тыва)Республикасы $-77 \%$ (2002)халық

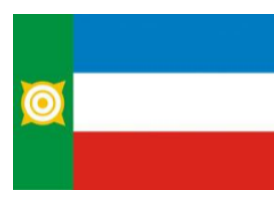

Хакас Республикасы $-12 \%$ (2002)халық

Алтай Республикасы 40\% (2002)халық

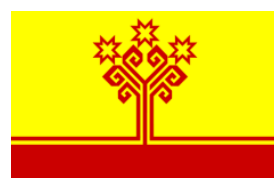

Чуваш Республикасы - $70 \%$ (2002) халык (чуваштар, татарлар)

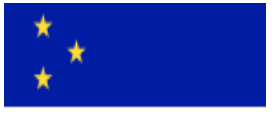

\section{Молдавия}

Гагауыз Республикасы 82 \% жуық (2004) халық

Қазіргі түркі тілдерін сипаттап, олар жайлы мәліметтер қорын жинақтау уақыттың талабы. Сонымен қатароның көпшіліктің пайдалануына ыңғайлы пішінде болуы көзделуде. Осы себептен де, бұл тақырыпты басқа ғылым салаларымен бірлікте қарастыру қажеттігі туып отыр. Түркі тілдес халықтардың таралымын көрсетуде лингвистика, жағрапия, информатика ғылымының бірлігінде қарау зор нәтиже беретініне, түрік дүниесі, түркі жұртының болашағынаөз үлесін қосатынына сенімдіміз. Түркі республикалары, түркі халықтары өзара саяси-экономикалық, мәдени-ағартушылық 
байланыстарды нығайтуда.Осы себептен және ғылым сұранысынаорай әлемдік ғаламтор желісінде түркі халықтарының жағрапиялық мәліметтер қорын түзу,қазіргі түркі тілдерінің таралымын көрсету, типологиялық төлқұжатын жасау өзекті тақырып болып саналады.

\title{
Пайдаланылван ддебиеттер тізімі:
}

1 Қажыбек Е. Ұльы дала тұлвалары: Жұбановтар тавылымы және жазу реформасы // Халықаралық вылылми-теориялық конферениия материалдары. - Алматы, 2019. - 6 б.

2 Төлеубаев Ә., Қасымбаев Ж., Қойгелдиев М., Қалиева Е., Далаева Т. Қазақстан тарихы // жалпы білім беретін мектептің қовамдық-гуманит. Бавытындавы 10- сыныбына арналван окулық. Алматы: Мектеп, 2010, 54 б. -кітап

3 Вакова Р.А., Бектемирова С.Б. ТҮркі филологиясына кіріспе. - Алматы, 2013. - 6 б. -кітап

4 Янсон Т. Тіл тарихы: Кіріспе - Алматы // Ұлттық аударма бюросы қзовамдық қ̧оры, 2019. 154 б. - Kiman

5 Barbara A. West., Encyclopedia of the Peoples of Asia and Oceania. 2008. - 826 6. -kiman

6 Асқұаров Н., Исхан Б.Ж., Зайсанбаев Т.Қ., Мәтбек Н.Қ., Оспанова Б.Р., Сабыр М.Б. Түркі тілдері: Ұжымдық монография. // Ш.Шаяхметов атындавы тілдерді дамытудың республикалық үйлестіру-ддістемелік ортальгвы РМҚК.-Астана, 2015. - 448 б. -монография

7 Авакова Р.А. ТҮркі өркениеті және тәуелсіз Қазақстан, I, - Астана, 2011, 596.

8 Бизақов С. Түбі бір түркілер. - Алматьл: 2013, 38 б. -кітап

9 Аманжолов А.С. Түркі филологиясының негіздері. - Алматы: Мектеп, 2012, 69 б. -кітап

10 Қайдар Ә., Оразов М. Түркітанува кіріспе. - Алматы: Арыс, 2004, 216 б. -кітап.

References:

1 Qajybek E. Ūly dala tūlğalary: Jūbanovtar tăgylymy jäne jazu reformasy // Halyqaralyq ğylymi-teorialyq konferensia materialdary. - Almaty, 2019. - 6 b.

2 Töleubaev Ä., Qasymbaev J., Qoigeldiev M., Qalieva E., Dalaeva T. Qazaqstan tarihy // jalpy bulım beretın mekteptıñ qoğamdyq-gumanit. Băgytyndağy 10- synybyna arnal̆̆an oqulyq. - Almaty: Mektep, 2010, 54 b. kıtap

3 Vakova R.A., Bektemirova S.B. Türkı filologiasyna kırıspe. - Almaty, 2013. - 6 b. -kitap

4 İanson T. Til tarihy: Kırlspe - Almaty // Ülttyq audarma bürosy qoğamdyq qory, 2019. - 154 b. -kıtap

5 Barbara A. West., Encyclopedia of the Peoples of Asia and Oceania. 2008. - 826 b. -kitap

6 Asqarov N., İshan B.J., Zaisanbaev T.Q., Mätbek N.Q., Ospanova B.R., Sabyr M.B. Türkı tılderı: Üjymdyq monografia. // Ş.Şaiahmetov atyndağy tılderdı damytudyñ respublikalyq üilestıru-ädıstemelık ortalyğy RMQK.- Astana, 2015. - 448 b. - monografia

7 Avakova R.A. Türkı örkenietı jäne täuelsı Qazaqstan, I, - Astana, 2011, 59 b.

8 Bizaqov S. Tübı bir türkller. - Almaty: 2013, 38 b. -kitap

9 Amanjolov A.S. Türk filologiasynyñ negızderı. - Almaty: Mektep, 2012, 69 b. -kıtap 10 Qaidar Ä., Orazov M. Türkıtanuğa kırıspe. - Almaty: Arys, 2004, 216 b. -kıtap. МРНТИ 16.31 .02

\section{МРНТИ 16.31.02}

\author{
Садық Д.А., ${ }^{1}$ Мәдиева Г.Б. ${ }^{2}$ \\ 1,2 әл-Фараби атындавы ҚазҰУ, \\ Алматы , Қазақсстан
}

\section{КОМПЬЮТЕРЛІК ЛИНГВИСТИКА КЕНІСТІГІНДЕГІ ЭЛЕКТРОНДЫ СӨЗДІКТЕРДІН АРТЫҚШЫЛЫҒЫ}

Аң̧датпа

Мақалада компьютерлік лингвистиканың бір саласы - қолданбалы лексикографияның даму динамикасына назар аударылған. Лексикография саласында еңбек еткен ғалымдардың еңбектеріне шолу жасалып, сан тарап пікірлеріне талдау жасалды. Интернет және технология салаларының дамуына байланысты лексикография саласы да жаңа бағыт бойынша даму алды. Компьютерлік лексикографияның жаңа саласы, жалқы есімдердің сөздік түзу тәжірибесін қарастыратын қолданбалы 